\title{
Life cycles, chaos and zoom lenses: a comparative analysis of some conceptual metaphors in the discourse of entrepreneurship theory
}

\section{Andy Arleo}

\section{OpenEdition \\ Journals}

\section{Electronic version}

URL: http://journals.openedition.org/asp/2017

DOI: $10.4000 / a s p .2017$

ISBN: 978-2-8218-0382-4

ISSN: 2108-6354

Publisher

Groupe d'étude et de recherche en anglais de spécialité

\section{Printed version}

Date of publication: 31 December 2000

Number of pages: 19-32

ISSN: $1246-8185$

\section{Electronic reference}

Andy Arleo, "Life cycles, chaos and zoom lenses: a comparative analysis of some conceptual metaphors in the discourse of entrepreneurship theory », ASp [Online], 27-30 | 2000, Online since 27 December 2010, connection on 22 April 2019. URL : http://journals.openedition.org/asp/2017 ; DOI : 10.4000/asp.2017

This text was automatically generated on 22 April 2019

Tous droits réservés 


\title{
Life cycles, chaos and zoom lenses: a comparative analysis of some conceptual metaphors in the discourse of entrepreneurship theory
}

\author{
Andy Arleo
}

\section{Introduction}

1 Entrepreneurship ${ }^{1}$ researchers have recognized the importance of language in the entrepreneurial process. According to William Gartner, one of the leading specialists in the field,

the choice of words we use to define entrepreneurship set the boundaries for how we think about and study it. Language governs thought and action. The vocabulary used to talk about entrepreneurship is critical to the development of a theory about this phenomenon. (Gartner 1993: 232) ${ }^{2}$

2 Nevertheless, it may be noted that while management studies have often used disciplines such as mathematics, psychology and sociology, they have less frequently explored the language within and about organizations (Girin 1990: 38). As for the study of metaphor, Morgan (1989) is an important contributor to the study of the dominant images that influence organizations, but does not deal specifically with metaphors in an entrepreneurship context. Koiranen (1995), on the other hand, does examine the metaphors associated with entrepreneurship and entrepreneur, based on data collected from 320 North European respondents, $28 \%$ of whom had experience in setting up or running a company. However, the methodology used by Koiranen differs considerably from that of the present study, which focuses on academic discourse about entrepreneurship. 
The aim of this article is to identify and analyze some conceptual metaphors found in a corpus of twelve influential articles on entrepreneurship theory. Section 1 presents the theoretical framework, the contemporary cognitive theory of metaphor developed by Lakoff and Johnson (1980 and 1999) and their collaborators. Section 2 briefly describes the criteria used to construct the corpus and deals with other methodological issues. Section 3, the main part of the article, is devoted to the analysis of three types of conceptual metaphor found in entrepreneurship discourse: a natural metaphor from biology, a series of abstract metaphors from physics and mathematics, and a technological metaphor from photography. The conclusion proposes a model for comparing these metaphor types in regard to originality and comprehensibility.

\section{A cognitive approach to metaphor}

The theoretical framework used in this article is based on the cognitive theory of metaphor that has been developed by linguist George Lakoff, philosopher Mark Johnson and other researchers since the late 1970s (Lakoff \& Johnson 1980; Johnson 1987; Lakoff \& Turner 1989; Sweetser 1990; Lakoff and Johnson 1999). ${ }^{3}$ For Lakoff and Johnson (1980: 5), "the essence of metaphor is understanding and experiencing one kind of thing in terms of another." More precisely, metaphor involves a cognitive mapping between two conceptual domains, a source domain and a target domain. In general, metaphor works successfully when a well-known source domain allows us to understand a lesser-known target domain. We may take an example that will be examined in greater detail in Section 3: A COMPANY IS A HUMAN BEING or more generally AN ORGANIZATION IS AN ORGANISM (see Morgan 1986). In this case, the source domain involves biological concepts and the target domain involves social organization. Using the familiar concepts of the source domain allows us to understand complex entities such as companies, as when we talk about the "head" or the "brains" of a firm. Furthermore, once the metaphorical mapping is established, we can develop a whole set of correspondences between the two domains and also transfer logical inferences from source to target. For example, when a human being is sick, we diagnose the illness and prescribe treatment; likewise, when a company is in poor health, the causes of the illness must be analyzed and remedies found.

The term conceptual metaphor refers to a systematic mapping between conceptual domains, whereas a particular example of a conceptual metaphor is called a metaphorical expression (Lakoff 1993: 209). In the above example, AN ORGANIZATION IS AN ORGANISM is a conceptual metaphor and " $\mathrm{X}$ is the head of the company" is a metaphorical expression. By convention, conceptual metaphors are in small capitals and metaphorical expressions are in lower case. It should be remembered that in this model metaphors are cognitive in nature and that verbal descriptions, such as LOVE IS A JOURNEY, are simply mnemonic devices to refer to a set of correspondences between conceptual domains. Unlike many traditional theories, in the cognitive approach the metaphor is not restricted to literature, rhetoric or even language, but is a basic and indispensable feature of human understanding. At this point, it may be useful to review some aspects of metaphor that have been underscored in recent research. This brief discussion is limited to four issues: the universality of metaphor, the acquisition of metaphor by the child, a possible neural basis for primary metaphors, and the understanding of metaphor. 
6 Metaphorical thinking appears to be widespread and has been found in all the languages studied by Lakoff and his collaborators (Lakoff 1997: 166). Anthropologist Donald Brown considers that metaphor is a human universal (Brown 1991: 132), a claim already stated over sixty years ago by the well-known anthropologist Franz Boas: "metaphor is universal, and the word meanings that stimulate metaphors undergo constant change" (Boas 1938, cited by Brown 1991: 161). This does not of course imply that all particular metaphorical expressions are universal. For example, the many baseball metaphors used in American English are obviously linked to a specific cultural context. On the other hand, some conceptual metaphors may be universal or nearly universal. For example, it appears that morality is usually associated with light and immorality with darkness (Lakoff 1997: 167).

7 Metaphorical thought is not only widespread among adults, but "the beginnings of metaphorical thought and language appear early in children's cognitive and linguistic development" (Glucksberg 1999: 536). At two months, the child can detect correspondences between sensorial modalities, which represents "a rudimentary form of metaphorical conceptualization" (ibid.). Furthermore, "children as young as two years can use and understand more abstract metaphorical correspondences, such as between the shoulders of a person and those of a mountain [...]" (ibid.).

8 The most basic metaphors, called "primary metaphors", are anchored in our experience of the world. For example, an expression like "Prices are going up" belongs to a conceptual metaphor linking quantity and verticality: MORE IS UP. This metaphorical mapping derives from our everyday experience: when we pour water into a glass, we see the level rise. According to a neural model developed by Srini Narayanan, a primary metaphor like MORE IS UP involves "a neurally instantiated correlation between (1) a sensorimotor operation (such as a determination of a degree or change of verticality) and (2) a subjective experience of judgement (such as a judgement of degree or change of quantity). The conflation of these two is the simultaneous activation of their respective neural networks." (Lakoff \& Johnson 1999: 55-56). Like atoms that combine to form molecules, these primary metaphors are the elementary building blocks of more complex metaphors (ibid:: 60ff).

9 Finally, in the traditional view, metaphors are seen as implicit comparisons that are understood by converting " $\mathrm{X}$ is a $\mathrm{Y}$ " to the simile form " $\mathrm{X}$ is like a $\mathrm{Y}$ ". However, psycholinguistic research has shown that subjects actually take less time to understand direct metaphors like "My lawyer is a shark" than similes like "My lawyer is like a shark" (Glucksberg 1999: 536).

10 How can the contemporary cognitive theory of metaphor outlined above contribute to a better understanding of entrepreneurship? Morgan (1989: 399-400) notes that organizations are many things at once; they can be viewed as machines, organisms, cultures, political systems, and so on. The use of these different metaphors leads to a better understanding of complex entities like companies and other social organizations. Because it deals with thought and not just language, the cognitive theory of metaphor is a cross-disciplinary enterprise that ties together the strands of diverse research traditions, including linguistics, psychology, neural modelling and literary studies, giving it a potentially powerful empirical base. By using the concept of mapping between source and target domains, this model also provides a particularly clear framework for grasping the multiple facets of entrepreneurial thought and action. 


\section{The corpus and methodology}

11

\section{impressive. Hernandez (personal communication) estimates that at least 1,000 articles on} the subject are published a year in addition to a large number of Ph.D. dissertations. Consequently, we decided to construct a corpus based on a set of influential articles in the field, as determined by a bibliometric study. Bechade (1996) analyzed the bibliographies of 167 articles published in three well-known American entrepreneurship journals from October 1986 to April 1995: Entrepreneurship Theory and Practice (76 articles), Journal of Business Venturing (54 articles) and Journal of Small Business Management (37 articles). This allowed him to identify the most frequently cited research, i.e., 11 books, 7 sections of books and 12 academic articles. The corpus used in the present study is made up of these 12 articles, whose references are shown in Appendix 1 with the number of citations for each article. domain was the concept "entrepreneurship", which included the entrepreneurial process, the entrepreneurial product (i.e. the start-up), the entrepreneur, and entrepreneurship as a discipline. This identification stage was carried out manually for several reasons. First, the corpus was not in an electronic format. Second, and more importantly, concordancers cannot automatically identify metaphors; human judgement must intervene to determine whether a particular expression is metaphorical or not, which means there is room for disagreement. However, several precautions were taken to make the identification process as reliable as possible. By carefully defining the target domain, we excluded metaphors in our corpus that are commonly found in academic discourse, but that do not apply specifically to entrepreneurship. For example, the expressions "to build a theory" or "a flimsy theory", both found in our corpus, are special cases of the conceptual metaphor THEORIES ARE BUILDINGS (Lakoff \& Johnson 1980: 46), which is used very generally in academic discussion. Furthermore, we note that several authors explicitly claim that they are discussing metaphorical usage. Finally, in the case of the first conceptual metaphor discussed below (see 3.1), there is massive evidence showing that the company is metaphorically conceptualized as an organism or species (see Morgan 1989). Although the present study is not quantitative in nature, it does provide data that might be used in a corpus linguistics approach, for example, some biological terms identified here, such as spawn, might be searched automatically in a large electronic corpus from the fields of economics and management.

Once identified, the metaphors were classified according to source domain, as shown below. The analysis that follows is not intended to be exhaustive, but focuses on three significant categories of metaphor that were discovered. 


\section{Three types of conceptual metaphor on entrepreneurship}

\subsection{The company as an organism or species}

the corpus. This biological metaphor was used by all the authors, as shown by words like growth, environment, and resources. Although these are familiar, widespread metaphors in economic discourse, and even in everyday speech, the systematic analysis of examples from the corpus will show how they apply specifically to entrepreneurship. For the sake of convenience, references are provided only for the longer passages, but not for the shorter metaphorical expressions, which are often used by more than one author. organism: "chances of survival", "survivals of entrepreneurial firms" or "economic viability". In these circumstances, the entrepreneur must look after the health of the company by taking from the environment ("macroenvironment", "microenvironment" and "subenvironment") the resources that are necessary for survival ("gathers resources", "mobilizes resources", "combining resources"). A good "growth strategy" allows the company to adapt to a changing, or even turbulent, environment ("environmental turbulence") ${ }^{4}$. Otherwise, death will ensue: "Those organizations that are well adapted to their environments will survive, and those that are not will die." (Low \& MacMillan 1988: 144).

19 In the above examples, the company is metaphorically conceptualized both as an individual organism and as a living species that must adapt to an environment. As Lakoff \& Johnson (1999: 558) point out, "evolutionary theory is, in itself, an account of the survival of species in terms of adaptation to ecological niches." The conceptual metaphor THE COMPANY IS A SPECIES is illustrated by expressions such as "environmental selection 
procedures" and "competitively insulated niches". As an interpretative structure, metaphor highlights some facets of reality and dissimulates others; in this case, it reinforces a simplified version of Darwinian theory.

Conceptual metaphors of the form $\mathrm{X}$ IS AN ORGANISM OR SPECIES, whose source domain is biology, are particularly widespread, and possibly universal, since we are ourselves organisms belonging to a species, and throughout our lives we interact with other organisms and species. Morgan (1989: 72-78) comments on the strengths and weaknesses of this metaphor, and observes that it can lead us to believe that the unity and harmony we perceive in organisms may be transferred to organizational life. However, in the theoretical discourse on entrepreneurship, we have seen that the young company or start-up is conceptualized as a fragile organism threatened by a hostile environment and also as a species searching for an ecological niche. For the entrepreneur, the harmony, unity and homeostasis evoked by Morgan are goals to reach rather than existing attributes.

21 Another limit of this metaphor has to do with the notion of "life cycle". Johnson (1987: 119-121) observes that the CYCLE mental schema is deeply anchored in human experience through natural processes such as reproduction, heartbeat, breathing, day and night, seasons and so on. Furthermore, we project a rise and fall pattern onto this schema so that the life cycle is experienced as "moving from birth to the fullness of maturation followed by a decline toward death." (ibid.: 120). In our analysis of entrepreneurship discourse, we observed that the life cycle metaphor is commonly applied to companies (in marketing it is commonly applied to the product). Like all metaphors, this mapping is only partially revealing: natural life cycles are to a large degree determined by biological constraints, which is not the case for companies, although other social, economic and political factors make immortal enterprises a rare commodity.

\subsection{Catastrophe theory, chaos theory and quantum physics}

In the preceding section we analyzed a conventional and widespread natural metaphor that is used so often that its metaphorical nature is easily forgotten. In this section we will look at a more original series of abstract metaphors that has been explored by William Bygrave (1989a and 1989b). Before becoming an entrepreneurship scholar, Bygrave earned a doctorate in physics and created two high-tech enterprises. In these two influential articles (see Appendix 1), he examines the entrepreneurship paradigm and compares it to other research traditions in the physical and social sciences. The metaphors used by Bygrave to understand the entrepreneurial process come mainly from catastrophe theory, chaos theory and quantum physics.

Bygrave notes that certain entrepreneurship researchers believe that catastrophe theory and chaos theory can supply appropriate metaphors for understanding the initial phases in a new business:

Catastrophe and chaos are two very entrancing theories of the new golden age. They provide a mathematics for systems in which very tiny changes in input make large differences to outcomes. To some entrepreneurship scholars that appears to be a good metaphor for the start-up of a new venture. (Bygrave 1989b: 8)

Furthermore, catastrophe theory and entrepreneurship do seem to share some common ground: 
Catastrophe theory is not a theory of sudden great disasters, but is instead a mathematical theory of systems that suddenly jump from one stable state to another. As such, it has a simplistic parallel with entrepreneurship... (ibid.: 11) Bygrave examines three differential equations displaying chaos. First, he demonstrates that venture capital behavior in the real world cannot be shown to be chaotic. Then he looks at a simpler chaotic system that can be applied to many situations in biology (population growth), genetics, epidemiology and other fields. This is a particularly interesting case to study since the "population-ecology theory seems to provide one of the more robust models of entrepreneurial start-ups, survivals, and failures... (ibid.: 21). We can see that this theory is based on THE COMPANY AS AN ORGANISM OR SPECIES studied in the preceding section. Bygrave notes that the chaotic region of this equation "has the feel of a model of entrepreneurship". (ibid.: 24). However, it is unlikely that such an equation can be applied directly to real-world businesses because it would imply very high growth rates over long periods of time:

Stated approximately, a value of 3.57 means a period-to-period growth rate of $257 \%$ in the early periods of a system that starts with very small initial values of $\mathrm{X}$. There may be situations in biology and epidemiology where populations grow that fast and exhibit chaotic behavior (e.g., populations of lynx [...]), but it is difficult to think of a business situation where such a fast growth rate was sustained for very many periods, whether the periods were years, or-and this is much less likelymonths. (ibid.: 24)

29

ASp, $27-30 \mid 2000$ 
provide us with precise equations, they help us form and sharpen our philosophy and methodology." (ibid.: 28)

In the same article, Bygrave uses quantum physics to explain the difference between mega-entrepreneurial start-ups (high-potential companies like Federal Express, Apple or Genentech) and micro-entrepreneurial start-ups (part-time mom-and-pop businesses):

A mega-entrepreneurial start-up is a quantum jump, whereas a microentrepreneurial start-up is an infinitesimal step. We can place them on a spectrum with individual quantum jumps at one end and continua at the other end. (ibid.: 10)

31 In the preceding section, we noted that the source domain of the conceptual metaphor A COMPANY IS AN ORGANISM OR SPECIES is anchored in our everyday embodied experience, which explains the ubiquity of these types of metaphorical mappings. On the other hand, the source domains of the metaphors examined by Bygrave are extremely abstract, to such a point that even for specialists it is difficult, if not impossible, to understand these concepts without resorting to metaphor. Indeed, mathematicians and physicists frequently use metaphorical language and imagery to name the phenomena they study: "catastrophes", "quantum jumps", "flavors" (for varieties of quarks), "strings" (see Lakoff \& Johnson 1999: 229-230), and so on..$^{5}$ The gist of Bygrave's research is that theories imported from the "hard sciences" do not appear to provide appropriate empirically testable models for entrepreneurship, but are better seen as metaphors. However, as pointed out previously, metaphorical thinking typically works when the source domain is well-known and can therefore shed light on the target domain. The source domains of the abstract metaphors described above appear to be so complex and hard to understand (without recourse to more basic metaphors) that one wonders whether they can be revealing for most entrepreneurs and entrepreneurship scholars.

\subsection{The entrepreneurial zoom lens}

Unlike Bygrave, Bird (1988: 448) uses a much more tangible source domain, photography, to understand the entrepreneurial process. She notes that entrepreneurs must cope with complexity, moving from operational detail to overall strategy, where the "big picture" is important. The entrepreneur also shifts from an inside view of the firm, involving operations and staffing for example, to an outside view, involving, for instance, customers and competition. To deal with this complexity and these shifts in perspective, the effective entrepreneur develops "a psychological, social, and strategic 'zoom lens'." ( ibid.) This photographic metaphor is extended in the following passage:

Like the camera lens, the strategic zoom lens allows the entrepreneur to see both close-up and at a distance. The lens allows him or her to adjust the depth of field, or the amount of detail made visible. The zoom quality of the lens allows for a rapid shift in the framework of any specific decision or action, and it is one way of coping with the temporal tension previously discussed. In this way, the lens makes visible both the details and the big picture. (ibid.: 448-449)

Bird argues that the entrepreneur needs both narrow focus, with attention to detail, as well as wider focus, in order to identify new products, markets, resources and so on.

The "zoom lens" metaphor developed by Bird to describe entrepreneurial psychology is actually derived from a much more basic metaphor: KNOWING OR UNDERSTANDING IS SEEING (Lakoff \& Johnson 1980, 1999, Sweetser 1990). This mapping between visual perception and cognition is found in many metaphorical expressions, such as "I see what you mean", 
"to shed light on a subject", "to have a bright idea" or "clear arguments" (as opposed to "muddy" or "murky") and so forth. Sweetser (1990: 37-40) observes that vision and intellection are linked for several reasons. First of all, vision is the only sense that allows us to focus precisely on a stimulus in our environment and to shift quickly from one stimulus to another. Furthermore, and more importantly, vision is considered the primary, most direct and most reliable source of objective information about the world, as shown notably by child-language studies and cross-linguistic studies of evidentials. Finally, vision allows us to obtain information from a distance about objects that do not emit sounds or smells, or may not easily be touched. Vision is therefore an ideal source domain for conceptualizing knowledge and understanding of the world. Bird's rather original metaphor is a variant of the VISION 㬝 KNOWLEDGE OR UNDERSTANDING mapping, where "zoom lens" replaces "vision".

\section{Conclusion}

We have focused on three types of conceptual metaphor used to understand entrepreneurship. THE COMPANY AS AN ORGANISM OR SPECIES can be considered a natural metaphor. As the source domain is close to human experience, this is a very common, conventional and easy to understand metaphorical mapping, and undoubtedly one learned early in life. On the other hand, the second series of metaphors, discussed by Bygrave, are highly abstract and much less accessible since the source domains involve mathematical and physical theories that are so abstruse that even specialists resort to metaphor to understand them. Finally, the technological metaphor proposed by Bird, the entrepreneurial zoom lens, is both original (although it is ultimately derived from the a more fundamental and ubiquitous metaphor KNOWING OR UNDERSTANDING IS SEEING), and easy to grasp, because it is based on what has become a well-known artefact.

Over the centuries, theorists have often discussed two dimensions in the use of metaphor, originality and comprehensibility. One of the frequently touted virtues of metaphor, especially literary metaphor, is that it allows us to see the world in new interesting ways. A second virtue is that metaphor enables us to understand the unfamiliar in terms of the familiar. The opposing view is that metaphor actually clouds our understanding and therefore deludes us about the nature of the world. The word dimension is used here to suggest that the originality and comprehensibility of metaphors are actually continuums that are related to many factors, including culture, age and individual background knowledge. The diagram below schematizes the three types of metaphor we have examined along these two dimensions: 
Figure 1. Three types of conceptual metaphor in relation to the dimensions of originality and comprehensibility

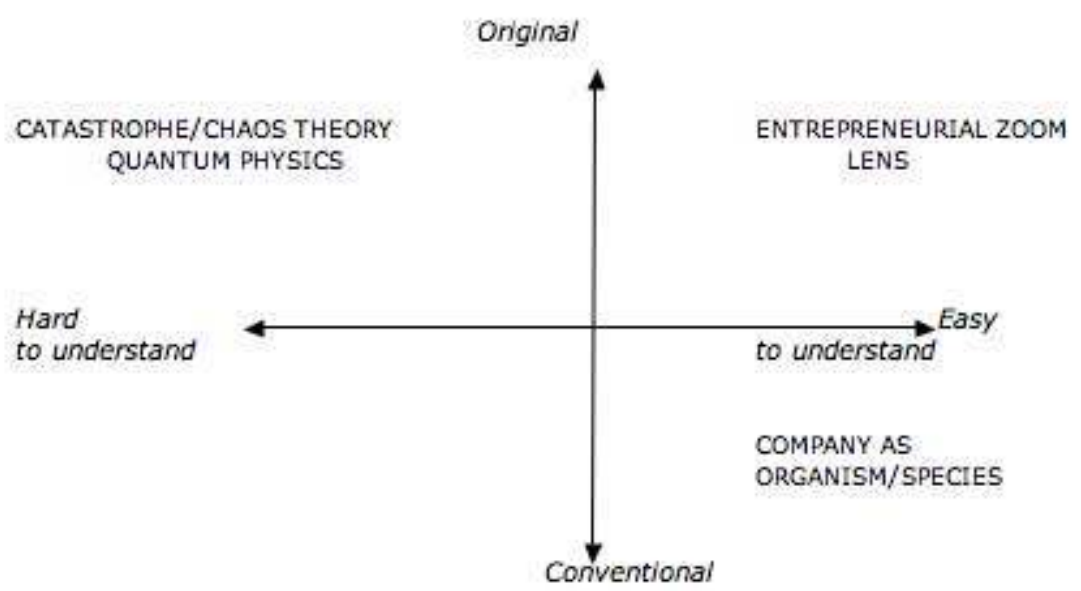

Figure 1 does not claim that some metaphors are inherently "good" and others "bad". The "success" of a metaphorical message depends on the goals of the sender (indeed, obfuscation is often a pragmatic objective), the context, the audience and so on. ${ }^{6}$ The above diagram, which does not aim to be rigorous in the quantitative sense, allows us to clarify the issues. There is often a trade-off between the two dimensions: natural metaphors like THE COMPANY AS AN ORGANISM OR SPECIES tend to be high in comprehensibility and low in originality, whereas the diagonally opposed abstract metaphors proposed by Bygrave are more original but harder to grasp. On the other hand, some metaphors, like the entrepreneurial zoom lens, appear to combine originality and intelligibility. If the goal is to enhance the understanding of an audience, such metaphors may be considered successful.

This research has been conducted in collaboration with the Centre d'étude et de recherche en entrepreneuriat (CERE) of the IUT de Saint-Nazaire, Université de Nantes, and in particular with my colleague Emile-Michel Hernandez, now Professeur des universités en Sciences de gestion at the Université de Reims, whom I wish to thank for introducing me to entrepreneurship studies. I would also like to thank the participants at the GERAS workshop for their comments. Special thanks to Kathryn English and Monique Mémet for their encouragement and their many helpful comments and suggestions.

\section{BIBLIOGRAPHY}

Bechade, Jean-Pierre. 1996. "Comprendre le champ de l'entrepreneurship". Cahier de recherche, 96/01/01. Chaire d'entrepreneurship Maclean Hunter, HEC Montréal.

Bird, Barbara. 1988. "Implementing entrepreneurial ideas: the case for intention". Academy of Management Review 13/3, 442-453. 
Boas, Franz ed. 1938. General Anthropology. Boston: Heath.

Brown, Donald. E. 1991. Human Universals. New York: McGraw Hill, Inc.

Bygrave, William D. 1989. “The Entrepreneurship paradigm (I): A philosophical look at its research methodologies”. Entrepreneurship, Theory and Practice 14/1, 7-26.

Bygrave, William D. 1989. “The Entrepreneurship paradigm (II): Chaos and catastrophes among quantum jumps?". Entrepreneurship, Theory and Practice, 14/2, 7-30.

Carland, James W. et al. 1984. "Differentiating entrepreneurs from small business owners: a conceptualization". Academy of Management Review 9/2, 354-359.

Carland, James W., Frank Hoy \& Jo Ann C. Carland. 1988. “'Who is an entrepreneur?' is a question worth asking”. American Journal of Small Business 12/4, 33-39.

Churchill, Neil C. and Virginia L. Lewis. 1983. "The five stages of small business growth". Harvard Business Review May-June, 30-50.

English, Kathryn. 1998. “Understanding science: when metaphors become terms”. ASp, 19-22, 151-163.

Gartner, William B. 1985. "A conceptual framework for describing the phenomenon of new venture creation". Academy of Management Review 10, 696-706.

Gartner, William B. 1988. “'Who is an entrepreneur?' is the wrong question”. Entrepreneurship Theory and Practice 13/4, 47-67.

Gartner, William B. 1990. "What are we talking about when we talk about entrepreneurship?". Journal of Business Venturing 5/1, 15-28.

Gartner, William B. 1993. "Words lead to deeds: Towards an organizational emergence vocabulary". Journal of Business Venturing 8/3, 231-239.

Girin, Jacques. 1990. "Problème du langage dans les organisations”. In Chanlat J.-F. (ed.), L'individu dans l'organisation : les dimensions oubliées, sous la direction de Paris: Presses de l'Université de Laval - Editions ESKA, 37-77.

Gleick, James. 1987. Chaos: Making a New Science. New York: Penguin Books.

Gleick, James. 1993. Genius: The Life and Science of Richard Feynman. New York: Vintage Books.

Glucksberg, Sam. 1999. "Metaphor”. In Wilson, Robert A. and Frank C. Keil (eds.), The MIT

Encyclopedia of the Cognitive Sciences. Cambridge, Ma.: MIT Press.

Johnson, Mark. 1987. The Body in the Mind. Chicago: University of Chicago Press.

Katz, Jerome and William B. Gartner. 1988. "Properties of emerging organizations". Academy of Management Review 13/3, 429-441.

Koiranen, Matti. 1995. “North-European metaphors of 'Entrepreneurship' and 'An

Entrepreneur". Frontiers of Entrepreneurship Research, 203-216.

Lakoff, George. 1987. Women, Fire, and Dangerous Things. What Categories Reveal about the Mind. Chicago: University of Chicago Press.

Lakoff, George. 1993. "The contemporary theory of metaphor". In Ortony, Andrew (ed.), Metaphor and Thought, $2^{\text {nd }}$ ed. Cambridge: Cambridge University Press.

Lakoff, George. 1997. “Les universaux de la pensée métaphorique: variations dans l'expression linguistique”. In Fuchs C. and S. Robert (eds.), Diversité des langues et représentations cognitives. Paris: Ophrys. 
Lakoff, George and Mark Johnson. 1980. Metaphors We Live By. Chicago: University of Chicago Press. Trad. fr., 1985. Les métaphores de la vie quotidienne. Paris: Éd. Minuit.

Lakoff, George and Mark Johnson. 1999. Philosophy in the Flesh. Chicago: University of Chicago Press.

Lakoff, George and Mark Turner. 1989. More than Cool Reason A Field Guide to Poetic Metaphor. Chicago: University of Chicago Press.

Low, Murray B. and Ian C. MacMillan. 1988. "Entrepreneurship: Past research and future challenges". Journal of Management 14/2, 139-161.

Morgan, Gareth. 1989. Images de l'organisation. Quebec: Les Presses de l'Université Laval. Trad. fr., 1986. Images of Organization. Beverly Hills: Sage Publications.

Resche, Catherine. 1998. “De l'Europe à l'euro ou 'l'industrieuse activité de la langue':

recensement et analyse des néologismes en anglais et en français de 1991 à 1998”. ASp 19-22, 185-208.

Sokal, Alan and Jean Bricmont. 1997. Impostures intellectuelles. Paris: Odile Jacob.

Sweetser, Eve. 1990. From Etymology to Pragmatics Metaphorical and cultural aspects of semantic structure. Cambridge: Cambridge University Press.

Wortman, Max S., Jr. 1987. "Entrepreneurship: an integrating typology and evaluation of the empirical research in the field". Journal of Management 13/2, 259-279.

\section{APPENDIXES}

\section{Appendix 1}

List of twelve most frequently cited articles in Entrepreneurship Theory and Practice (76 articles), Journal of Business Venturing (54 articles) and Journal of Small Business Management (37 articles) from October 1986 to April 1995.

\begin{tabular}{|l|l|}
\hline Reference & Number of Citations \\
\hline Bygrave 1989a and 1989b & 27 \\
\hline Gartner 1985 & 24 \\
\hline Low and Macmillan 1988 & 21 \\
\hline Carland, Hoy, Boulton and Carland & 20 \\
\hline Gartner 1988 & 20 \\
\hline Wortman 1987 & 18 \\
\hline Katz and Gartner 1988 & 14 \\
\hline Churchill and Lewis 1983 & 14 \\
\hline Carland, Hoy and Carland 1988 & 12 \\
\hline
\end{tabular}




\begin{tabular}{|l|l|}
\hline Bird 1988 & 12 \\
\hline Gartner 1990 & 10 \\
\hline
\end{tabular}

\section{NOTES}

1. An earlier version of this paper was presented at the GERAS conference in Dijon, March 15-18, 2000.

2. The French Académie de l'Entrepreneuriat defines entrepreneuriat as follows: “Au sens large, le champ de l'entrepreneuriat couvre tous les aspects de l'engagement de l'entrepreneur, tant professionnels que personnels, qui apparaissent lors de la création de l'entreprise et tout au long du cycle de vie de celle-ci. Il s'étend aussi à la fonction sociétale de l'entrepreneur et à ses manifestations dans des contextes culturels variés. » For Gartner (1988: 62), « Entrepreneurship is the creation of new organizations [...] Entrepreneurship ends when the creation stage of the organization ends."

3. See also English (1998) for a useful discussion of contemporary metaphor theory in relation to terminology.

4. Resche (1998: 73) shows that metaphors relating to natural disasters, such as earthquakes, hurricanes and flooding, are often used to describe financial crises (see also the discussion of catastrophe theory in section 3.2. below).

5. Gleick (1993: 244), in his biography of physicist Richard Feynman, points out that "most physicists could not eschew visualization. They found that they needed imagery." In his inimitable way, Feynman attempted to describe his own thinking process: "What I am really trying to do is bring birth to clarity, which is really a half-assedly thought-out pictorial semivision thing. I would see the jiggle-jiggle-jiggle or the wiggle of the path [...] It's all visual. It's hard to explain." (ibid.).

6. The controversy sparked by Sokal and Bricmont (1997) had to do with the appropriateness of metaphors used by some researchers in the social sciences. The book was not an attack on metaphor per se, but a critique of metaphors that, in the authors' view, create obscurity rather than clarity.

\section{ABSTRACTS}

This article analyzes some conceptual metaphors found in a corpus of twelve influential articles on entrepreneurship published between 1986 and 1995. Section 1 presents the theoretical framework, the cognitive theory of metaphor developed by Lakoff and Johnson and their collaborators (Lakoff \& Johnson 1980, 1999; Johnson 1987; Lakoff \& Turner 1989; Sweetser 1990) and underlines the advantages of this model compared to more traditional approaches. Section 2 deals with methodological issues. Section 3 analyzes three types of conceptual metaphor found in entrepreneurship discourse: a natural metaphor from biology (the company as an organism or species), a series of abstract metaphors from catastrophe theory, chaos theory and quantum physics, and finally a technological metaphor from photography (the entrepreneurial zoom lens). 
Cet article analyse quelques métaphores conceptuelles dans un corpus de douze articles majeurs dans le domaine de l'entrepreneuriat, publiés entre 1986 et 1995. L'auteur présente d'abord le cadre théorique de ce travail, la théorie cognitive de la métaphore élaborée par Lakoff, Johnson et leurs collaborateurs (Lakoff \& Johnson 1980, 1999; Johnson 1987, Lakoff \& Turner 1989; Sweetser 1990) et souligne ses avantages par rapport à des approches plus traditionnelles. Il traite ensuite des questions méthodologiques. La troisième partie est consacrée à l'analyse de trois types de métaphores dans le discours sur l'entrepreneuriat: une métaphore naturelle, qui provient de la biologie (l'entreprise en tant qu'organisme or espèce), une série de métaphores abstraites tirées de la théorie des catastrophes, de la théorie du chaos et de la physique quantique, et enfin une métaphore technologique (l'objectif zoom de l'entrepreneur).

\section{INDEX}

Mots-clés: cycle de vie, entrepreneuriat, métaphore, objectif zoom, organisme, physique quantique, théorie des catastrophes, théorie du chaos

Keywords: entrepreneurship, life cycle, metaphor, organism, quantum physics, theory (catastrophe), theory (chaos), zoom lens

\section{AUTHOR}

ANDY ARLEO 